удк 339

DOI: https://doi.org/10.32851/2708-0366/2020.3.3

Повод T.M.

кандидат економічних наук, доцент, доцент кафредри економіки та фрінансів, Херсонський державний аграрно-економічний університет ORCID: https://orcid.org/0000-0001-8191-5488

Адвокатова Н.О.

кандидат економічних наук, доцент, доцент кафредри економіки та фрінансів,

Херсонський державний аграрно-економічний університет ORCID: https://orcid.org/0000-0003-2027-7464

Povod Tetiana

Kherson State Agrarian and Economic University

Advokatova Nadiia

Kherson State Agrarian and Economic University

\title{
СУЧАСНІ ТЕНДЕНЦІЇ ФІНАНСОВОЇ ГЛОБАЛІЗАЦІЇ
}

\section{CURRENT TRENDS OF FINANCIAL GLOBALIZATION}

Досліджено особливості глобалізаичійних проичесів, а також їх вплив на сучасні тендениіі розвитку світового фінансового простору. Проаналізовано кониепиї виникнення фінансової глобалізації, розглянуто теоретичні основи фінансової глобалізації, окреслено підходи до економічної сутності даного явища. Визначено позитивні та негативні сторони сучасного розвитку глобалізаційних процесів. Узагальнено існуючі ризики фінансової глобалізації для ринку країни, розглянуто переваги глобалізачійних прочесів і їх загрози для інвестичійної безпеки краӥни, зроблено висновки, щчодо можливих перспектив. Визначено щзо поглиблення фінансової глобалізащії залежить від розвитку економіки краӥни, розглянуто загальні рекомендації щзодо державної політики Украӥни в умовах інтеграції до світової економіки.

Ключові слова: глобалізачія, фінансова глобалізація, фінансовий ринок, перспективи, інтеграція, інвестиціiі.

Исследованы особенности глобализационных процессов и их влияние на современные тенденциии развития мирового пространства. Проанализированы концепции развития финансовой глобализации, рассмотрены теоретические основы финансовой глобализацчии, определены подходы к экономической сущтности данного явления. Определены положительные и отрицательные сторонь современного развития глобализационных проицессов. Обобщены сущчествующче риски финансовой глобализации для рынка страны, рассмотрены преимущества глобализационных процессов и их угрозь для инвестииионной безопасности страны, сделаны выводы относительно возможных перспектив. Раскрыто, что внедрение финансовой глобализации зависит от развития экономики страны, рассмотрены общие рекомендации по государственной политики Украины в условиях интеграции в мировую экономику.

Ключевые слова: глобализация, финансовая глобализация, финансовый рынок, перспективы, интеграция, инвестициии.

A significant factor that reflects the state of international relations and the development of the world community are the processes of globalization, which involve a large number of countries that differ in their economic and political development. The process of formation of the global economy and financial globalization cannot be avoided. A characteristic feature of financial globalization is the possibility of free movement of financial capital, the formation of a single market and close cooperation between countries. That is why it is necessary to determine the priorities of Ukraine's participation in globalization, in order to use it to increase 
the competitiveness of the domestic economy and create effective mechanisms to minimize its negative consequences. Globalization is a leading factor in revolutionary trends in the modern economy. With the development of foreign economic relations between countries, there are more and more opportunities to spread first national and then world product. The degree of positive impact of globalization processes depends on the place and role of each country in the world environment. The globalization of financial markets involves the removal of barriers between domestic and international markets and the development of multifaceted links between sectors, so the concept of stability is fundamental to the modern world economy, because without a sufficient level of stability of national and global financial markets financial sector. As noted above, the process of globalization has spread most in the financial sector. Information technology has made it possible to connect the world's financial centers, reduce the time of transactions and reduce their cost. The wave of mergers and acquisitions in developed countries and the deregulation of the economy in the last decades of the last century have led to the emergence of financial holdings. The financial market began to develop from its own sources, separating itself from the real economy. The state loses control over the movement of private capital, which determines the economic situation in most countries. A new global decision-making mechanism is being formed with a new composition of participants.

Key words: globalization, financial globalization, financial market, prospects, integration, investments.

Постановка проблеми. Значним фактором, що відображає стан міжнародних відносин та розвиток світової спільноти є процеси глобалізації, в яких бере участь велика кількість країн, що різняться своїм економічним і політичним розвитком. Процесу становлення глобальної економіки та фінансової глобалізації не можна уникнути. Характерною особливістю фінансової глобалізації $є$ можливість вільного руху фінансового капіталу, становлення єдиного ринку та тісна взаємодія країн. Саме тому є необхідним визначення пріоритетів участі України в глобалізації, з метою використання іiї для підвищення конкурентоспроможності вітчизняної економіки та створення ефективних механізмів для мінімізації ії негативних наслідків.

Аналіз останніх досліджень і публікацій Проблемам формування фінансової системи в сучасних умовах глобалізаційних процесів присвячено численні праці як вітчизняних так і зарубіжних дослідників: В. Довгалюк, Л. Коваль, О. Кукарцева, Н. Копинець, Р. Робертсона, Дж. Сороса, Н. Стукало, І. Стукан, Н. Ткаченко, С. Циганова та ін. Хоча окремі аспекти глобалізаційних процесів порівняно широко висвітлені в економічній літературі, але виникають нові складні питання, пов'язані з постійними змінами

Отже, виникає об'єктивна необхідність у досліджені вказаних проблем з метою їх подальшого розв'язання.

Формулювання цілей статті. Визначення сучасних позитивних і негативних тенденцій фінансового глобалізаційного розвитку

Виклад основного матеріалу дослідження. Глобалізація $є$ провідним чинником революційних тенденцій у сучасній економіці. 3 розвитком між країнами зовнішньоекономічних зв'язків, з'являються все нові і нові можливості поширення спочатку національного, а потім і світового продукту. Ступінь позитивного впливу від процесів глобалізації залежить від місця та ролі кожної країни у світовому середовищі.

Сьогодення свідчить про відсутність єдності стосовно генезису як глобалізації загалом, так і зокрема фінансової глобалізації [1, с. 18].

Термін «глобалізація»- один з найуживаніших, і водночас один із найбільш беззмістовних визначень у сучасній суспільній теорії. Якщо простежувати його виникнення, треба визнати, що він з'явився у перші повоєнні роки та еволюціонував із дієслова «глобалізувати» (to globalize), наявність якого як самостійного поняття зафіксована ще у 1950-ті pp. На початку 1970-х рр. європейські управлінці використовували для позначення зростаючої взаємозалежності національних економік французьке слово 
mondialisation, із зворотного перекладу якого англійською виникла «глобалізація» у тому значенні цього слова, у якому його зараз застосовують. До середини 1990-х рр. концепція глобалізації, у межах якої цей процес тлумачився як один 3 найважливіших в умовах сучасного світу, була поширена настільки широко, що М. Вотерс писав: «Подібно тому, як основним поняттям 80-х рр. був постмодернізм, ключовою ідеєю 90-х рр. може стати глобалізація, під якою ми розуміємо перехід людства у третє тисячоліття» [3, с. 28] (таблиця 1).

Таблиця 1

\section{Історична еволюція поняття глобалізація}

\begin{tabular}{|c|c|}
\hline Дата & Подія, визначення \\
\hline 1944 рік & $\begin{array}{l}\text { Американські дослідники О. Рейзер та Б. Девіс у праці «Планетарна демократія» } \\
\text { неодноразово використовували поняття globalize та globalism [3] }\end{array}$ \\
\hline 1981 рік & $\begin{array}{l}\text { Дж. Маклін поставив у центр концептуального дослідження термін «глобалізація» } \\
\text { (від англ. «global» земна куля), він закликав «зрозуміти історичний процес } \\
\text { наростання глобалізації соціальних відносин і дати йому пояснення» }[1 ; 3]\end{array}$ \\
\hline 1983 рік & $\begin{array}{l}\text { Поняття «глобалізація» вжито Т. Левітт, як феномен злиття ринків окремих } \\
\text { продуктів, які виробляються великими багатонаціональними корпораціями [1] }\end{array}$ \\
\hline 1983 рік & $\begin{array}{l}\text { Британський дослідник Р. Робертсон вперше вжив термін globality у назві однієї } \\
\text { із своїх статей [3; 5] }\end{array}$ \\
\hline 1984 рік & $\begin{array}{l}\text { Дефініцію «глобалізація» (globalization) використано у редакційному коментарі } \\
\text { «Wall-Street Journal» щодо рішення М. Тетчер відкрити іноземним банкам прямий } \\
\text { доступ на фінансовий ринок лондонського Сіті [1] }\end{array}$ \\
\hline 1985 рік & $\begin{array}{l}\text { Р. Робертсон надав докладне тлумачення поняття globalization і визначив даний } \\
\text { процес як «сукупність об’єктивно фіксованих явищ, які мають на меті об’єднання } \\
\text { світу в єдине ціле» [4; 6] }\end{array}$ \\
\hline 1992 рік & Р. Робертсон виклав основи власної концепції у спеціальному дослідженні [3; 7] \\
\hline 1997 рік & $\begin{array}{l}\text { У Річному звіті МВФ «Глобалізація: можливості та проблеми» наведено } \\
\text { визначення глобалізації як економічної взаємозалежності країн усього світу в } \\
\text { результаті зростаючого обсягу й різноманітності міжнародних операцій [4] }\end{array}$ \\
\hline
\end{tabular}

Джерело: складено авторами

У свою чергу, Дж. Сорос під глобалізацією розуміє «...розвиток глобальних фінансових ринків, зростання могутності транснаціональних корпорацій і зростаючий вплив останніх на національні економіки» [4].

На думку Дж. Сороса, глобалізація не тільки створює додаткове багатство, а й додаткову свободу, в чому і полягає основний ії позитивний аспект. Саме глобалізаційні процеси можуть привести до створення глобального відкритого суспільства, яке забезпечить набагато більший рівень свободи, ніж це може забезпечити будь-яка національна держава, і саме в цьому є основний позитивний аспект глобалізації $[12 ; 13 ; 15 ; 16]$.

К. Паркінз у середині 90-х років XX ст. відзначав, що поняття «глобалізація» може використовуватися щонайменше в чотирьох значеннях: як нове відчуття всесвітнього взаємозв'язку; як загальні господарські стратегії або шлях до досягнення загального управління; як процес змін, який посилює зв'язки (міжнародні, регіональні, соціальні тощо); як суспільні, соціальні відносини через сприйняття світу як єдиної мобільної системи [4].

Протягом двох останніх десятиліть термін «глобалізація» використовується для позначення наростаючої взаємозалежності світу - економічної, соціокультурної та політичної. Характерно, що він вважається настільки зрозумілим, що більшість авто- 
рів не дають йому визначення навіть у роботах, безпосередньо присвячених теорії глобалізації [3].

Сьогодні глобалізація охоплює майже всі сфери життєдіяльності людини і її вплив стає дедалі відчутнішим. Економічна траєкторія глобалізації полягає у виникненні та функціонуванні великої кількості транснаціональних компаній, що володіють величезними ресурсами і здатних реалізовувати глобальні за своїми масштабами проекти; значному зростанні транснаціональних потоків капіталів, товарів, людських ресурсів; бурхливому розвитку міжнародної торгівлі, зростанні міжнародної спеціалізації та кооперації, поєднанні в процесі спеціалізації торгівлі з виробничою діяльністю і спрощенні митних бар'єрів; створенні транснаціональної світової мережі перевезень, транспортування газу, нафти, передачі електроенергії; формуванні світової інформаційної мережі Інтернет та їі використанні в комерційній, політичній, культурній, інформаційній цілях; створенні та підвищенні ролі міждержавних інститутів як регуляторів не лише політичних, а й економічних відносин [4].

Одним із основних глобалізаційних сегментів, зокрема у сфері економіки, безумовно, є фінансова сфера (фінансова глобалізація), погляди на яку істотно різняться і яка все більше впливає на світовий економічний простір [1, с. 19] (таблиця 2).

Дефініція поняття «фінансова глобалізація»

Таблиця 2

\begin{tabular}{|l|l|}
\hline \multicolumn{1}{|c|}{ Автор } & \multicolumn{1}{|c|}{ Визначення } \\
\hline Чуб О.О. & $\begin{array}{l}\text { Фінансова глобалізація - це процес об’єднання в єдину світову систему всієї } \\
\text { сукупності міжнародних фінансових відносин [1; 8]. }\end{array}$ \\
\hline Стукало Н.В. & $\begin{array}{l}\text { Фінансова глобалізація - вільний та ефективний рух капіталів між країнами } \\
\text { та регіонами, функціонування глобального ринку, формування системи } \\
\text { наднаціонального регулювання міжнародних фінансів, реалізація глобальних } \\
\text { фінансових стратегій ТНК та транснаціональних банків [1]. }\end{array}$ \\
\hline Ткаченко Н.В. & $\begin{array}{l}\text { Фінансова глобалізація є складовою частиною глобалізації усього світового } \\
\text { господарства і наслідком економічної інтеграції, інтенсивно розвинулася } \\
\text { протягом другої половини минулого століття. Відповідно, вона являє собою } \\
\text { фінансову взаємозалежність країн всього світу, що виникла в результаті } \\
\text { зростачого обсягу міжнародних фінансових угоді світових потоків капіталу } \\
\text { з використанням множини фінансових інструментів, а також у зв'язку з } \\
\text { впровадженням сучасних електронних технологій, засобів комунікації та } \\
\text { інформатизації [9]. }\end{array}$ \\
\hline $\begin{array}{l}\text { Сергіо } \\
\text { Шмуклер }\end{array}$ & $\begin{array}{l}\text { Фінансова глобалізація - інтеграція внутрішніх національних фінансових } \\
\text { систем у міжнародні фінансові ринки та інститути [10]. }\end{array}$ \\
\hline $\begin{array}{l}\text { Міркін Я.М. } \\
\text { Міркін В.Я. }\end{array}$ & $\begin{array}{l}\text { Глобалізація фінансових ринків - процес стирання кордонів між націо- } \\
\text { нальними ринками, інтеграції фінансових інструментів, учасників ринку, } \\
\text { органів регулювання, механізмів торгівлі цінними паперами стандартизації } \\
\text { правил тощо [1]. }\end{array}$ \\
\hline
\end{tabular}

Джерело: складено авторами

Глобалізація фінансових ринків передбачає усунення бар'єрів між внутрішніми та міжнародними ринками й розвиток багатоваріантних зв'язків між окремими секторами, тому поняття стабільності є фундаментальним для сучасної світової економіки, оскільки без достатнього рівня стійкості національних і світових фінансових ринків неможливо забезпечити економічне зростання й надійне функціонування фінансового сектора [1].

Як було вище зазначено, найбільше процес глобалізації поширився у фінансовій сфері. Інформаційні технології дали можливість поєднати разом фінансові центри світу, скоротити час укладання угод та знизити їх вартість. Хвиля злиття й поглинань 
у розвинутих країнах і нерегульованість економіки останніми десятиріччями минулого століття призвели до виникнення фінансових холдингів. Фінансовий ринок став розвиватися за рахунок власних джерел, відособлюючись від реальної економіки. Держава втрачає контроль над рухом приватного капіталу, який визначає економічну ситуацію в більшості країн світу. Формується новий глобальний механізм прийняття рішень із новим складом учасників [4].

Основу глобалізації складають зміни на фінансових ринках, які $є$ різновидом системної асиметрії економічного розвитку. Системна асиметрія на глобальному фінансовому ринку та ринку інвестицій має два аспекти: територіальний (на економічно розвинені країни припадає $75 \%$ обсягу всіх операцій), та функціональний (фактична концентрація капіталів в економічно розвинених країнах, а саме, на 20\% населення світу, яке живе в економічно розвинених країнах припадає $86 \%$ світового ВВП, а на 20\% найбідніших економічно слаборозвинених країн - тільки $1 \%$ ВВП) $[12 ; 15 ; 16]$.

Посередниками на глобальному фінансовому ринку (фінансовому просторі) виступають транснаціональні компанії (ТНК), транснаціональні банки (ТНБ) та міжнародні організації. ТНК забезпечують інтенсивний рух фінансових ресурсів між кордонами країн. Важливим є те, що на вітчизняний ринок приходять компанії зі світовим ім'ям та значним досвідом (Raiffeisen International Bank Holding, BNP Paribas Group). Відповідно ТНБ здійснюють розрахункові операції в банках-партнерах з різних країн, але й мають за кордоном дочірні банківські установи, відкривають власні філії. Поява іноземних банків та залучення дешевих кредитних ресурсів в Україну повинна була б зменшити відсоткові ставки, однак через неекономічні причини досі така перевага лібералізації економіки не використовується в країні.

Міжнародні фінансові організації формують валютно-фінансові зв'язки між усіма групами країн. Крім цього міжнародним організаціям відведена роль регулятора світового валютно-фінансового простору. На сьогодні нараховується безліч організації, які сприяють вирішенню глобальних економічних проблем у світовому середовищі [2].

Необхідно зазначити наступні недоліки фінансової глобалізації:

- асиметричність результатів для різних груп країн (переваги отримують лише розвинуті країни), що призводить до виникнення конфліктів на регіональному, національному та інтернаціональному рівнях;

- нестабільність світової фінансової системи, що спричиняє регіональну та глобальну нестабільність через взаємозалежність національних фінансових систем на світовому рівні;

- зниження регуляторної ролі національних держав, що підсилює значення наднаціональних утворень та впливу ТНК;

- дестабілізація економіки через масовий відтік капіталу, що призводить до підриву стабільності курсу національної грошової одиниці та зниження золотовалютного резерву;

- зростання світової заборгованості країн за зовнішніми запозиченнями, що призводить до боргової залежності країн-боржників від країн-кредиторів;

- поширення використання офшорних зон у міжнародному бізнесі, що призводить до приховування неоподатковуваних коштів від національного та міжнародного контролю [2; 11; 13].

Ключовим моментом в науковому дослідженні фінансової глобалізації є з'ясування причин підвищеного динамізму у фінансовій складовій процесу глобалізації. 3 цього питання можна виділити такі аспекти:

- по-перше, поява та розвиток нових інформаційних технології забезпечили створення системи фінансових центрів. Варто зазначити, що це вплинуло на суттєве зниження не лише трансакційних витрат з реалізації фінансових угод, але й необхідного для них часу; 
- по-друге, відбулася модернізація існуючого та формування нового інструментарію фінансового ринку, зокрема інструментів хеджування та управління ризиками. Окрім того підвищена ризикованість викликала необхідність введення нових інструментів, так званих похідних цінних паперів - деривативів;

- по-третє, фінансові інститути отримали можливість більш широкої діяльності. Це виражається в розширені та зміні власників активів, у зниженні обов'язкових платежів із фінансових трансакцій, у формуванні мережі офшорних банків, які зокрема працюють у пільговому режимі, тощо [9, с. 83].

До фінансової глобалізації долучилися майже всі країни світу, у тому числі й Україна. Першими фактичними ознаками участі України у процесах фінансової глобалізації почали з'являтися з надходження прямих іноземних інвестицій у кінці 1990-х на початку 2000-х рр. На сьогодні основними напрямами фінансової глобалізації є: розвиток банківської сфери; розвиток фондового ринку; розвиток ринку фінансових послуг. До форм фінансової глобалізації можна віднести: глобалізацію фінансових інструментів (переміщення капіталу, поява інноваційних цінних паперів) та глобалізація фінансових інститутів (розширення меж для співпраці інвестора $з$ потенційним об’єктом інвестування, розширення спектру фінансових послуг) $[2 ; 15 ; 16]$.

Загрози для економічної безпеки України які по'вязані з фінансовою глобалізацією, можна поділити на дві групи: загрози, пов'язані з не контрольованістю процесів; загрози, пов'язані з неефективністю економічної політики національних держав.

Насамперед проблема загроз стосується фінансових ринків країн, що розвиваються, оскільки саме ці ринки зазнають значних змін в процесі глобалізації з наступних причин: зростання обсягу іноземних капіталів, інвестованих у національну економіку; гармонізації національного законодавства; збільшення кількості учасників національних фінансових ринків $[12 ; 15 ; 16]$.

Фінансова глобалізація створює для України суттєві переваги, а саме:

- збільшення фінансової допомоги з боку міжнародних фінансових організацій (зокрема МВФ);

- розширення зв'язків з основними учасниками глобального фінансового ринку ТНК і міжнародними фінансовими організаціями;

- збільшення інвестицій (надходження яких регулюється глобальними ТНК);

- сприяє інноваційному розвитку (нові технології фінансових ринків) що підвищує якість послуг на фінансовому ринку;

- активізація конкуренції за рахунок збільшення представництва на ринку іноземних фінансових інституцій.

Відповідно, фінансова глобалізація створює і для розвитку економіки України серйозні загрози і ризики, зокрема:

- залежність національного фінансового ринку від глобального, що посилює процеси вивезення капіталу, збільшує зовнішній борг і може призвести до втрати економічної незалежності держави;

- вигоди фінансової глобалізації розділяються нерівномірно;

- посилення залежності фінансових посередників від інтересів іноземних інвесторів;

- швидкість трансмісійних кризових явищ, специфіка яких відображається через поняття «ефект доміно» та «ефект резонансу»;

- зростання складності системи глобального фінансового ринку підвищує загальну нестабільність цієї системи, а мобільність фінансового ринку стає передумовою фінансових криз $[9 ; 12 ; 15 ; 16]$.

В Україні фінансова криза характеризується насамперед ослабленням зв'язків між найважливішими елементами фінансової системи держави, хронічною незбалансованістю бюджетних доходів і видатків, розбалансованістю грошово-кредитної системи, відсутністю стабільності курсу національної валюти, лавиноподібним зрос- 
танням державної заборгованості, нераціональною структурою бюджетних витрат, неоптимальним рівнем податкових вилучень для формування бюджетів усіх рівнів. Економіка України почала дедалі відчувати вторинні наслідки, пов'язані також із світовою фінансовою кризою, а саме: зростання вартості та утруднення отримання зовнішніх запозичень; витік капіталу; зниження попиту на провідних експортних ринках України; наростання негативних очікувань суб'єктів ринку під впливом демонстраційного ефекту світової кризи $[13 ; 14]$.

Існує думка про те, що ситуація, коли країна знаходиться в стадії фінансової кризи, є найбільш сприятливою для проведення реформ, оскільки населення країни та інші суб'єкти економічної діяльності усвідомлюють необхідність змін і готові сприйняти їх адекватно. Криза не лише руйнує, а й містить у собі конструктивний потенціал - зосереджується на перспективі, формує передумови утвердження нового. Криза - це не лише великі втрати та випробування. Це водночас і прискорення модернізації сучасного світоустрою, підгрунтя для утвердження нового, перспективного.

Однак, у прагненні до позиціонування такого явища, як криза у позитивному світлі, слід не забувати про соціальний аспект. Зростання макроекономічних показників за рахунок стресів $[11 ; 13 ; 14]$.

Висновки. Проведене дослідження свідчить, що поглиблення фінансової глобалізації залежить від розвитку економіки країни. Сьогодні Україна бере активну участь у процесах фінансової глобалізації, але через повільний розвиток в усіх сферах економіки, країна не здатна інтегрувати до світового фінансового ринку, плідно співпрацювати з іноземними партнерами. Виникає необхідність керування процесами глобалізації в інтересах розвитку національної економіки, тому що зупинити ці процеси у фінансовій сфері не можливо. Процеси інтеграції потребують розробки національної моделі розвитку вітчизняного фінансового ринку, в основі якої має бути гармонізація існуючої нормативно-правової бази щодо фінансових ринків із європейським і міжнародним законодавством.

Підсумовуючи все вище наведене, можна виділити той факт, що вагоме місце у глобалізації займає держава. Саме державна фінансова політика має вчасно реагувати на всі чинники можливого економічного зростання через вдало сформовану податкову політику, грошово-кредитну політику, соціальну політику, інвестиційну політику та інші види фінансової політики. Було б доцільним, поглибити і розширити напрями проведення державної підтримки вітчизняного бізнесу для його подальшого розвитку в умовах євроінтеграції. Країна повинна шукати шляхи співпраці з новими ринками, новими інструментами які $є$ найбільш актуальними для сьогодення. Розширяти свою участь у процесах фінансової глобалізації банківського, страхового та фондового ринків. Відповідно, дослідження основних проблем і переваг від інтеграції у глобальний фінансовий простір є надзвичайно актуальними.

\section{Список використаних джерел:}

1. Стукан І.Ю. Фінансова глобалізація: сутність, етапи та наслідки. Європейські перспективи, 2015. № 1. С. 18-24.

2. Довгалюк В.В. Роль фінансової глобалізації у розвитку фінансового ринку. Ефективна економіка, 2016. №7. URL: http://nbuv.gov.ua/UJRN/efek_2016_7_26 (дата звернення: 25.10.2020).

3. Кукарцев О.В. Дослідження і теоретизування глобалізації: до історії питання. Україн-ська начіональна ідея: реалії та перспективи розвитку, 2014. Вип. 26. С. 27-31. URL: http://nbuv.gov.ua/UJRN/Unir_2014_26_7 (дата звернення: 24.10.2020).

4. Копинець Н. Г. Сучасні тенденції глобалізації фінансових ринків. Облік і фінанси АПК. URL: http://magazine.faaf.org.ua/suchasni-tendencii-globalizacii-finansovih-rinkiv.html (дата звернення: 26.10.2020).

5. Robertson R. Interpreting Globality. World Realities and International Studies / Ed. by R. Robertson. Glenside. - PA : Pennsylvania Council on International Education, 1983. P. 7-20. 
6. Robertson R. The Relativization of Societies: Modern Religion and Globalization. Cults, Culture, and the Law: Perspectives on New Religious Movements / Ed. by Thomas Robbins, William C. Shepherd and James McBride. - Chicago : Scholars Press, 1985. P. 31-42.

7. Robertson R. Globalization: Social Theory and Global Culture. London : Thousand Oaks, CA: Sage Publications, 1992. $224 \mathrm{p}$.

8. Чуб О.О. Банки в глобальній економіці : монографія. Київ : КНЕУ, 2009. 340 с.

9. Ткаченко Н.В. Вплив глобалізаційних процесів на розвиток фінансових посередників. Наукові записки Наиіонального університету «Острозька академія», серія «Економіка», 2014. Вип. 26. С.82-88.

10. Schmukler S. Financial Globalization: Gain and Pain for Developing countries. Economic Review. Second Quarter 2004. Federal Reserve Bank of Atlanta. 2004. 83 p.

11. Kavun S., Zhosan G. Influence Determination of Social Responsibility to the Productivity Enterprise Activity Level. Economies, 2016. No. 4 (3), p. 14; DOI: 10.3390/economies4030014. Available from: http://www.mdpi.com/2227-7099/4/3/14/html (дата звернення: 25.10.2020).

12. Коваль Л.А., Романчук С.А., Фабрика І.В. Фінансова глобалізація: загрози і переваги для інвестиційної безпеки України. Наукові праиі Кіровоградського наџіонального технічного університету. Економічні науки. 2012. Вип. 21. C. 224-230. URL: http://nbuv.gov.ua/UJRN/ Npkntu_e_2012_21_33 (дата звернення: 26.10.2020).

13. Yurii Kyrylov, Natalia Kyrychenko, Tatyana Stukan and Hanna Zhosan (2020) Formation of Enterprise Management Strategies and Entrepreneurship Training.InternationalJournalof Management, no. 11 (6), pp. 793-800. Available at: http://www.iaeme.com/MasterAdmin/Journal_uploads/ijm/ VOLUME_11_ISSUE_6/IJM_11_06_067.pdf (дата звернення: 25.10.2020).

14. Циганов С.А. Вплив глобалізації світової економіки на розвиток фінансового ринку. Зовнішня торгівля: економіка, фінанси, право, 2014. № 3 (74). С. 105-115.

15. Zhosan G., Shandova N. (2015) Determination of the relationship enterprise's responsibilities with components social responsibility. Conference Proceedings " 5 th International Conference on Application of Information and Communication Technology and Statistics in Economy and Education ICAICTSEE 2015", November 13 - 14th, 2015, University of National and World Economy Sofia, Bulgaria, pp. 340-356. Available at: http://icaictsee.unwe.bg/past-conferences/ICAICTSEE-2015.pdf (дата звернення: 25.10.2020).

16. Yuriy Kyrylov, Viktoriia Hranovska, Hanna Zhosan, Inna Dotsenko (2020) Innovative Development of Agrarian Enterprises of Ukraine in the Context of the Fourth Industrial Revolution. Solid State Technology. Vol. 63. Issue 6. Publication Year: 2020. Pp. 1430-1448.

\section{References:}

1. Stukan I. Yu. (2015) Finansova hlobalizatsiya: sutnist', etapy ta naslidky [Financial globalization: essence, stages and consequences]. Yevropeys'ki perspektyvy, no. 1, pp. 18-24.

2. Dovhalyuk V.V. (2016) Rol' finansovoyi hlobalizatsiyi u rozvytku finansovoho rynku [The role of financial globalization in the development of the financial market]. Efektyvna ekonomika, no. 7, Available at: http://nbuv.gov.ua/UJRN/efek_2016_7_26 (accessed 25 October 2020).

3. Kukartsev O.V. (2014) Doslidzhennya i teoretyzuvannya hlobalizatsiyi: do istoriyi pytannya [Research and theorizing of globalization: to the history of the question]. Ukrayins'ka natsional'na ideya: realiyi ta perspektyvy rozvytku, vol. 26, pp. 27-31. Available at: http://nbuv.gov.ua/UJRN/ Unir_2014_26_7 (accessed 24 October 2020).

4. Kopynets N.H. (2020). Suchasni tendentsiyi hlobalizatsiyi finansovykh rynkiv [Modern tendencies of globalization of financial markets]. Oblik i finansy APK. Available at: http://magazine.faaf.org.ua/ suchasni-tendencii-globalizacii-finansovih-rinkiv.html (accessed 26 October 2020).

5. Robertson R. (1983) Interpreting Globality. World Realities and International Studies / Ed. by R. Robertson. Glenside. PA: Pennsylvania Council on International Education, pp. 7-20.

6. Robertson R. (1985) The Relativization of Societies: Modern Religion and Globalization. Cults, Culture, and the Law: Perspectives on New Religious Movements / Ed. by Thomas Robbins, William C. Shepherd and James McBride. - Chicago: Scholars Press, pp. 31-42.

7. Robertson R. (1992) Globalization: Social Theory and Global Culture. - London: Thousand Oaks, CA: Sage Publications, $224 \mathrm{p}$.

8. Chub O.O. (2009) Banky v hlobal'niy ekonomitsi [Banks in the global economy]. Kyiv: KNEU.

9. Tkachenko N.V. (2014) Vplyv hlobalizatsiynykh protsesiv na rozvytok finansovykh poserednykiv [Influence of globalization processes on the development of financial intermediaries]. Naukovi zapysky Natsional'noho universytetu «Ostroz'ka akademiya», seriya «Ekonomika», vol. 26, pp. 82-88. 
10. Schmukler S. (2004) Financial Globalization: Gain and Pain for Developing countries. Economic Review. Second Quarter 2004. Federal Reserve Bank of Atlanta.

11. Kavun S., Zhosan G. (2016) Influence Determination of Social Responsibility to the Productivity Enterprise Activity Level. Economies, no. 4 (3), p. 14. DOI: 10.3390/economies4030014. Available at: http://www.mdpi.com/2227-7099/4/3/14/html (accessed 25 October 2020).

12. Tsyhanov S.A. (2014) Vplyv hlobalizatsiyi svitovoyi ekonomiky na rozvytok finansovoho ryn$\mathrm{ku}$ [The impact of globalization of the world economy on the development of the financial market]. Zovnishnya torhivlya: ekonomika, finansy, pravo, no. 3 (74), pp. 105-115.

13. Kyrylov Y., Kyrychenko N., Stukan T., Zhosan H., (2020) Formation of Enterprise Management Strategies and Entrepreneurship Training. International Journal of Management, no. 11 (6), pp. 793-800. Available at: http://www.iaeme.com/MasterAdmin/Journal_uploads/ijm/VOLUME_11_ ISSUE_6/IJM_11_06_067.pdf(accessed 25 October 2020).

14. Tsyhanov S.A. (2014) Vplyv hlobalizatsiyi svitovoyi ekonomiky na rozvytok finansovoho ryn$\mathrm{ku}$ [The impact of globalization of the world economy on the development of the financial market]. Zovnishnya torhivlya: ekonomika, finansy, pravo, no. 3 (74), pp. 105-115.

15. Zhosan G., Shandova N. (2015) Determination of the relationship enterprise's responsibilities with components social responsibility. Conference Proceedings "5th International Conference on Application of Information and Communication Technology and Statistics in Economy and Education ICAICTSEE - 2015", November 13 - 14th, University of National and World Economy Sofia, Bulgaria, pp. 340-356. Available at: http://icaictsee.unwe.bg/past-conferences/ICAICTSEE-2015.pdf (accessed 25 October 2020).

16. Yuriy Kyrylov, Viktoriia Hranovska, Hanna Zhosan, Inna Dotsenko (2020) Innovative Development of Agrarian Enterprises of Ukraine in the Context of the Fourth Industrial Revolution. Solid State Technology. Vol. 63. Issue 6. Publication Year: 2020. Pp. 1430-1448. 